\title{
Retymicin, Galtamycin B, Saquayamycin Z and Ribofuranosyllumichrome, Novel Secondary Metabolites from Micromonospora sp. Tü 6368
}

\author{
II. Structure Elucidation \\ Karsten Ströch, Axel Zeeck, Noémi Antal, Hans-Peter Fiedler
}

Received: November 5, 2004 / Accepted: January 7, 2005

(C) Japan Antibiotics Research Association

\begin{abstract}
A detailed screening of the secondary metabolite pattern from Micromonospora sp. strain Tü 6368 resulted in the isolation of ten compounds belonging to five different structural families. The structures of the novel compounds 1-( $\alpha$-ribofuranosyl)-lumichrome (3), retymicin (7), galtamycin B (11) and saquayamycin Z (14) were assigned by spectroscopic methods and chemical transformations. This strain fits our hypothesis that the metabolite analysis of biosynthetically talented strains leads readily to novel compounds.
\end{abstract}

Keywords structure elucidation, Micromonospora, angucyclinones, tetracenequione glycosides, saquayamycin $\mathrm{Z}$, lumichromes

\section{Introduction}

The well established HPLC-DAD-screening resulted in the discovery of several secondary metabolites produced by Micromonospora sp. strain Tü 6368 under different cultivation conditions. Four of the isolated compounds turned out to be new: 1-( $\alpha$-ribofuranosyl)-lumichrome (3), retymicin (7), galtamycin B (11) and saquayamycin Z (14), the others were known: two lumichromes (1 and 2), three angucyclinones $(\mathbf{4} \sim 6)$ and one tetracenequinone (9). In the previous paper the taxonomy and fermentation as well as the isolation, characterisation and biological activities of

A. Zeeck (Corresponding author), K. Ströch: Institut für Organische und Biomolekulare Chemie, Universität Gottingen, Tammannstr. 2, D-37077 Göttingen, Germany, E-mail: azeeck@gwdg.de the secondary metabolites were described [1]. In this part we present the structure elucidation, which was done mainly by NMR analysis.

\section{Lumichromes}

Lumichrome (1) and 1-methyllumichrome (2) were identified by comparison of UV, HREI-MS as well as ${ }^{1} \mathrm{H}$ and ${ }^{13} \mathrm{C}$-NMR data with literature values (Fig. 1) [2]. The third yellow fluorescent compound of this family exhibited the molecular formula $\mathrm{C}_{17} \mathrm{H}_{18} \mathrm{~N}_{4} \mathrm{O}_{6}$, determined by HRESI$\operatorname{MS}\left(m / z=375.12972[\mathrm{M}+\mathrm{H}]^{+}\right)$, and differs from $\mathbf{1}$ by a $\mathrm{C}_{5^{-}}$ unit. Comparison of the ${ }^{1} \mathrm{H}$ and ${ }^{13} \mathrm{C}$ NMR spectra of $\mathbf{3}$ and $\mathbf{1}$ led to the assumption that a sugar moiety is added to the lumichrome skeleton. In conjunction with the ${ }^{1} \mathrm{H},{ }^{1} \mathrm{H}$ COSY spectrum the additional signals could be assigned to a pentofuranose. To determine the linkage of the sugar (position 1 or 3) an HMBC experiment with 3 was carried out and revealed interactions between $\mathrm{C}-2$ and $1^{\prime}-\mathrm{H}$ and $2^{\prime}$ $\mathrm{H}$, respectively, an expected cross signal between $\mathrm{C}-10 \mathrm{a}$ and $1^{\prime}-\mathrm{H}$ was missing. Nevertheless we assumed that the sugar is linked to N-1 due to the substitution pattern of 1methyllumichrome (2). To identify the sugar moiety, NOE experiments were carried out. Selective irradiations revealed correlations between $1^{\prime}-\mathrm{H}$ and $2^{\prime}-\mathrm{H}$ as well as $2^{\prime}-$ $\mathrm{H}$ and $3^{\prime}-\mathrm{H}$. The signals of $3^{\prime}-\mathrm{H}$ and $4^{\prime}-\mathrm{H}$ overlapped, thus no determination of a correlation was possible. Four possibilities are left for the configuration of the pentofuranose: $\alpha$-D- and $\alpha$-L-ribofuranose as well as $\beta$-D-

N. Antal, H.-P. Fiedler: Mikrobiologisches Institut, Universität Tübingen, Auf der Morgenstelle 28, D-72076 Tübingen, Germany 
<smiles>[Y1]c1cc2nc3c(=O)[nH]c(=O)n([R])c3nc2cc1C</smiles>

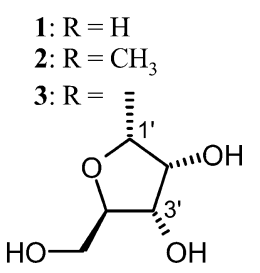

Fig. 1 Structural formulae of lumichromes (1 $\sim 3$ ).

and $\beta$-L-lyxofuranose. From the ${ }^{1} \mathrm{H}$ coupling constants between $1^{\prime}-\mathrm{H} / 2^{\prime}-\mathrm{H}, 2^{\prime}-\mathrm{H} / 3^{\prime}-\mathrm{H}$ (each with ${ }^{3} J=5.5 \mathrm{~Hz}$ ) and $3^{\prime}-\mathrm{H} / 4^{\prime}-\mathrm{H}\left({ }^{3} J=9.0 \mathrm{~Hz}\right)$ a ribofuranose was suggested. This was confirmed by GC-MS analysis after methanolysis of $\mathbf{3}$ followed by silylation. The Rt-values of the sugar peaks were compared with those of D-(-)-ribose and D-(-)lyxose after derivatisation under the same conditions. As a result 1-( $\alpha$-ribofuranosyl)-lumichrome (3) was identified, which has not been described in the literature so far (Fig. $1)$. The $\mathrm{D}$ - or L-configuration has not yet been determined. However 1-( $\beta$-D-ribofuranosyl)-, 3-( $\beta$-D-ribofuranosyl)-, and 1,3-di-( $\beta$-D-ribofuranosyl)-lumichromes are already known [3] as synthetic compounds.

\section{Angucyclinones}

The known angucyclinones, rabelomycin (4) [4], 3deoxyrabelomycin (5) [5] and dehydrorabelomycin (6) [6] were identified by comparison of HREI-MS, ${ }^{1} \mathrm{H}$ and ${ }^{13} \mathrm{C}$ NMR data with literature values (Fig. 2). The fourth compound, the main compound of the crude extract, was named retymicin (7), its molecular formula $\mathrm{C}_{18} \mathrm{H}_{16} \mathrm{O}_{6}$ was determined by HRESI-MS $\left(m / z=329.10259[\mathrm{M}+\mathrm{H}]^{+}\right)$. The ${ }^{1} \mathrm{H}$ and ${ }^{13} \mathrm{C}$ NMR spectra show signals for one methyl, two methylene, one aliphatic and five aromatic methine groups as well as nine quaternary carbon atoms. Two of these indicate oxygenated aliphatic carbon atoms $\left(\delta_{\mathrm{C}}=78.4\right.$ and 80.4) and two others at $\delta_{\mathrm{C}}=176.8$ and 209.3 point to a carbonyl group and a ketone, respectively. The ${ }^{1} \mathrm{H}$ NMR spectrum showed similarities to the rings $\mathrm{A}$ and $\mathrm{D}$ of 3-deoxyrabelomycin (5), therefore we assumed an angucyclinone variant. The ${ }^{1} \mathrm{H},{ }^{1} \mathrm{H}$ COSY experiment confirmed a 1,2,3-substituted aromatic system (ring D) and a 2,3,5-substituted cyclohexanone moiety (ring A). Additionally, a $\mathrm{Z}$ configurated double bond $\left(\delta_{\mathrm{H}}=6.47\right.$ and $6.52,{ }^{3} J=10.0 \mathrm{~Hz}$ ) was established. Due to the lack of a third carbonyl group in the ${ }^{13} \mathrm{C}$ NMR spectrum, retymicin (7) is not a quinone in ring C. In addition, ring B is not aromatic, the ${ }^{13} \mathrm{C}$ NMR spectrum reveals signals at $\delta_{\mathrm{C}}=78.4$ and 80.4 , which belong to ring B. Furthermore there are three signals at $\delta_{\mathrm{C}}=146.3,148.9$ and 162.1 typical for oxygenated quaternary aromatic carbon atoms. Consequently, there are only a carbonyl group and an oxygen atom remaining for ring $\mathrm{C}$. The structural elements could be unambiguously combined with the help of an HMBC experiment resulting in formula 7 (Fig. 2). Thus retymicin (7) is a xanthone derivative, which emerges biosynthetically from an angucyclinone such as ochracenomicin A (8) [7], compound 7 has not been described so far. The stereochemistry is shown according to known angucyclinones and is not yet proven.

\section{Tetracenequinone Glycosides}

Galtamycinone (9) could be identified by HREI-MS, ${ }^{1} \mathrm{H}$ and ${ }^{13} \mathrm{C}$ NMR data [8], structure 9 represents a $C$ glycosylated tetracenequinone and is the aglycone of galtamycin (10) [9]. The second isolated red compound of this structural family exhibited a similar UV spectrum as 9

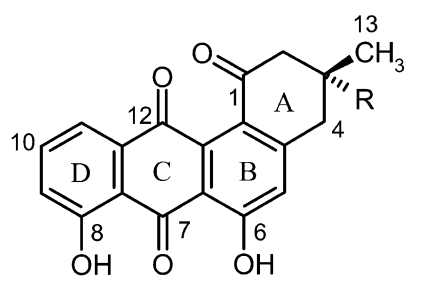

4: $\mathrm{R}=\mathrm{OH}$
5: $\mathrm{R}=\mathrm{H}$<smiles>Cc1cc(O)c2c3c(c(O)cc2c1)C(=O)c1c(O)cccc1C3=O</smiles>

6

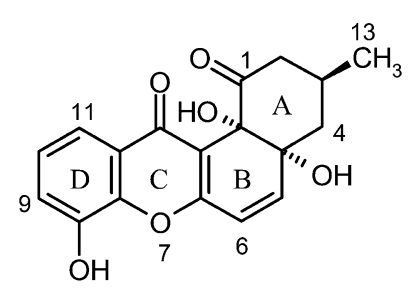

7<smiles>O=c1c2ccccc2oc2ccccc12</smiles>

xanthone skeleton<smiles>CC1CC2C(O)(C=CC(C(=O)c3cccc(O)c3)=C3C(=O)C(C)CC(=O)C32O)C1</smiles>

8

Fig. 2 Structural formulae of rabelomycins (4 $\sim \mathbf{6})$, retymicin $(\mathbf{7})$ and related compounds. 
and 10. Its molecular formula was assigned as $\mathrm{C}_{43} \mathrm{H}_{48} \mathrm{O}_{15}$ by HRESI-MS $\left(m / z=803.29204[\mathrm{M}-\mathrm{H}]^{-}\right)$in conjunction with its ${ }^{13} \mathrm{C}$ NMR spectrum. There is a difference of four mass units compared with $\mathbf{1 0}\left(\mathrm{C}_{43} \mathrm{H}_{52} \mathrm{O}_{15}\right)$, which is an $O$ glycoside of 9 with two $\alpha$-L-rhodinoses and one $\beta$-Dolivose as building blocks. By comparison of the ${ }^{13} \mathrm{C}$ NMR data (Table 1) with $\mathbf{9}$, it clearly turned out that $\mathbf{9}$ is the aglycone of the novel compound, named galtamycin B (11). It is noteworthy that four of the carbons of $\mathbf{1 1}$ could not be detected in spectra measured in pyridine- $d_{5}$ and three were not seen, if $\mathrm{CDCl}_{3}$ was used as a solvent.

Additionally to the ${ }^{13} \mathrm{C}$ NMR signals of 9 the signals of a trisaccharide moiety are visible (Table 1 ). Among these we identify signals for an $\alpha, \beta$-unsaturated ketone $\left(\delta_{\mathrm{C}}=127.3\right.$, $144.3,197.0)$, three anomeric carbon atoms $\left(\delta_{\mathrm{C}}=95.6\right.$, $99.0,99.2)$, three methyl groups $\left(\delta_{\mathrm{C}}=15.5,16.4,17.4\right)$, six oxygenated methine groups and three methylene groups. These data suggested three deoxy sugars, the structure of which could be determined with $2 \mathrm{D}$ NMR experiments $\left({ }^{1} \mathrm{H}\right.$, ${ }^{1} \mathrm{H}$ COSY, HSQC and HMBC) and by comparison with literature values of 2-deoxyfucose, rhodinose and aculose. The HMBC experiment gave the linkage of the sugars to the $\beta$-D-olivose of the aglycone $\left[\mathrm{CDCl}_{3}: 1 \mathrm{~A}-\mathrm{H}\left(\delta_{\mathrm{H}}=5.09\right)\right.$ to $\left.\mathrm{C}-4^{\prime}\left(\delta_{\mathrm{C}}=89.5\right)\right]$ and to each other $\left[\mathrm{CDCl}_{3}: 1 \mathrm{~B}-\mathrm{H}\right.$ $\left(\delta_{\mathrm{H}}=4.90\right)$ to $\mathrm{C}-4 \mathrm{~A}\left(\delta_{\mathrm{C}}=79.3\right) ; 1 \mathrm{C}-\mathrm{H}\left(\delta_{\mathrm{H}}=5.23\right)$ to $\mathrm{C}-4 \mathrm{~B}$ $\left.\left(\delta_{\mathrm{C}}=76.3\right)\right]$. The anomeric configurations of the three $O$ glycosidically bound sugars followed from the ${ }^{3} J_{\mathrm{H}, \mathrm{H}}$ coupling constants $(=3.5 \mathrm{~Hz})$ and turned out to be $\alpha$. Considering that an $\alpha$-O-glycosidic bond reveals a L-sugar we assigned the sequence of the trisaccharide as L-aculosyl$(1 \rightarrow 4)$ - $\alpha$-L-rhodinosyl-( $1 \rightarrow 4)-\alpha$-L-2-deoxyfucosyl, which is connected to $4^{\prime}-O$ of the aglycone. Thus formula $\mathbf{1 1}$ represents galtamycin $\mathrm{B}$, which is a novel tetracenequinone glycoside (Fig. 4).

Aculose is a rather reactive sugar and adds easily methanol to the double bond under acidic conditions resulting in 2-methoxycinerulose A (Fig. 3) [10, 11]. If methanol was used in the work-up procedure and the following chromatographic steps, we isolated the methanol adduct $\mathbf{1 2}$ instead of $\mathbf{1 1}$. The adduct $\mathbf{1 2}$ differs slightly in the Rf value from $11\left(\mathrm{CHCl}_{3}-\mathrm{MeOH} 9: 1: 0.68\right.$ and 0.62 , respectively) and exhibits the molecular formula $\mathrm{C}_{44} \mathrm{H}_{52} \mathrm{O}_{16}$ confirmed by HRESI-MS $\left(m / z=835.31881[\mathrm{M}-\mathrm{H}]^{-}\right)$. Significant in the ${ }^{13} \mathrm{C}$ NMR spectra of $\mathbf{1 2}$ compared with $\mathbf{1 1}$ is the loss of two olefinic carbon atoms, the shift of the carbonyl group from $\delta_{\mathrm{C}}=197.0$ to 207.6 and the additional methoxy $\left(\delta_{\mathrm{C}}=57.1\right)$, methine $\left(\delta_{\mathrm{C}}=78.9\right)$ and methylene groups $\left(\delta_{\mathrm{C}}=39.8\right)$. ESI-MS ${ }^{\mathrm{n}}$ experiments with 12 revealed the successive cleavage of 2-methoxycinerulose A, rhodinose, 2-deoxyfucose and olivose. These data proved the sequence of the sugar moieties of 12 (Fig. 4).
Table 1 Comparison of the ${ }^{13} \mathrm{C}$ NMR data of galtamycinone (9), galtamycin B (11) and the methanol adduct 12

\begin{tabular}{|c|c|c|c|c|}
\hline C-atom & $\begin{array}{l}\mathbf{9}^{\mathrm{a}} \\
\delta_{\mathrm{C}}\end{array}$ & $\begin{array}{l}\mathbf{1 1}^{\mathrm{a}} \\
\delta_{\mathrm{C}}\end{array}$ & $\begin{array}{c}\mathbf{1 1}^{\mathrm{b}} \\
\delta_{\mathrm{C}}\end{array}$ & $\begin{array}{c}\mathbf{1 2}^{\mathrm{b}} \\
\delta_{\mathrm{C}}\end{array}$ \\
\hline$C-1$ & 157.7 & 157.8 & 154.1 & 154.1 \\
\hline C-2 & 117.1 & 117.2 & 116.7 & 116.8 \\
\hline$C-3$ & 142.1 & 142.3 & 141.3 & 141.3 \\
\hline C-4 & 115.5 & 115.6 & n.d. & n.d. \\
\hline$C-4 a$ & 129.9 & $130.2^{\mathrm{c}}$ & 129.2 & 129.1 \\
\hline$C-5$ & 164.0 & n.d. & 163.5 & 163.2 \\
\hline$C-5 a$ & 109.9 & 110.0 & 109.4 & 109.3 \\
\hline$C-6$ & 187.0 & n.d. & 186.9 & 186.9 \\
\hline$C-6 a$ & 133.3 & n.d. & n.d. & n.d. \\
\hline $\mathrm{C}-7$ & 118.9 & 119.0 & 118.8 & 118.8 \\
\hline C-8 & 133.4 & 133.4 & 132.9 & 132.9 \\
\hline C-9 & 138.6 & 138.2 & 137.1 & 137.0 \\
\hline C-10 & 159.6 & 159.7 & 159.4 & 159.4 \\
\hline C-10a & 116.9 & 117.1 & 116.6 & 116.6 \\
\hline C-11 & 188.4 & $188.7^{\mathrm{c}}$ & 187.9 & 187.9 \\
\hline C-11a & 126.4 & n.d. & 126.3 & 126.2 \\
\hline C-12 & 118.0 & $118.1^{\mathrm{C}}$ & n.d. & n.d. \\
\hline$C-12 a$ & 125.9 & 126.1 & 124.6 & 124.6 \\
\hline$C-13$ & 22.2 & 22.2 & 22.2 & 22.2 \\
\hline $\mathrm{C}-1^{\prime}$ & 72.2 & 71.9 & 71.2 & 71.2 \\
\hline $\mathrm{C}-2^{\prime}$ & 41.1 & 40.6 & 38.4 & 38.4 \\
\hline$C-3^{\prime}$ & 73.5 & 71.6 & 71.4 & 71.4 \\
\hline$C-4^{\prime}$ & 78.7 & 86.4 & 89.5 & 89.5 \\
\hline$C-5^{\prime}$ & 77.5 & 75.9 & 74.4 & 74.3 \\
\hline$C-6^{\prime}$ & 19.0 & 19.0 & 18.6 & 18.6 \\
\hline $\mathrm{C}-1 \mathrm{~A}$ & - & 99.0 & 99.6 & 99.6 \\
\hline $\mathrm{C}-2 \mathrm{~A}$ & - & 33.9 & 32.3 & 32.2 \\
\hline C-3A & - & 66.8 & 66.8 & 66.8 \\
\hline$C-4 A$ & - & 79.4 & 79.3 & 79.1 \\
\hline$C-5 A$ & - & 64.5 & 64.6 & 64.5 \\
\hline C-6A & - & 16.4 & 16.1 & 16.1 \\
\hline $\mathrm{C}-1 \mathrm{~B}$ & - & 99.2 & 100.0 & 100.0 \\
\hline $\mathrm{C}-2 \mathrm{~B}$ & - & 24.9 & 24.4 & 24.5 \\
\hline C-3B & - & 25.0 & 24.6 & 24.6 \\
\hline$C-4 B$ & - & 76.9 & 76.3 & 75.6 \\
\hline C-5B & - & 67.2 & 67.1 & 67.2 \\
\hline C-6B & - & 17.4 & 17.1 & 17.2 \\
\hline C-1C & - & 95.6 & 95.3 & 100.6 \\
\hline $\mathrm{C}-2 \mathrm{C}$ & - & 144.3 & 142.9 & 78.9 \\
\hline$C-3 C$ & - & 127.0 & 127.4 & 39.8 \\
\hline C-4C & - & 197.0 & 196.7 & 207.6 \\
\hline$C-5 C$ & - & 70.9 & 70.6 & 72.0 \\
\hline C-6C & - & 15.5 & 15.1 & 14.9 \\
\hline C-7C & - & - & - & 57.1 \\
\hline
\end{tabular}

${ }^{a}$ pyridine- $d_{5},{ }^{b} \mathrm{CDCl}_{3}$

${ }^{c}$ chemical shift assignments were made on the bases of $\mathrm{C}-\mathrm{H}$ chemical shift correlation experiments

n.d. $=$ not detectable 


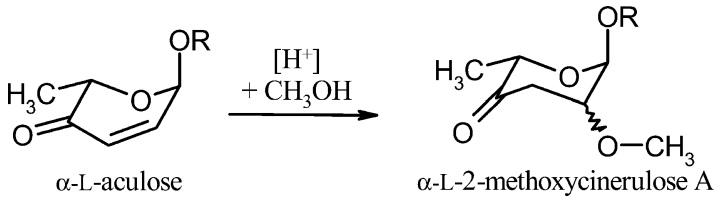

Fig. 3 Addition of methanol to L-aculose of galtamycin $B$ (11) and saquayamicin $Z$ (14) resulting in L-2methoxycinerulose $A$ of the methanol adducts 12 and $\mathbf{1 5}$, respectively.

\section{Saquayamycin $\mathbf{Z}$}

The comparison of the UV spectrum of the orange compound with the HPLC-UV/VIS database showed similarities to saquayamycin B [12], an angucycline with aquayamycin (13) [13] as aglycone. Looking for the molecular mass and formula of the compound by ESI-MS, the result was rather striking $\left(\mathrm{C}_{73} \mathrm{H}_{102} \mathrm{O}_{29}, \mathrm{~m} / z=1465.63952\right.$ $\left.[\mathrm{M}+\mathrm{Na}]^{+}\right)$and leads to the largest angucycline ever reported $[14,15]$. Thus we named the metabolite saquayamycin $Z$ (14). The ${ }^{13} \mathrm{C}$ NMR data of the aglycone were in full agreement with those of other saquayamycins. Compared with 13, additional signals for eight anomeric carbon atoms $\left(\delta_{\mathrm{C}}=92.6 \sim 101.4\right)$ and eight methyl groups $\left(\delta_{\mathrm{C}}=15.1 \sim 18.0\right)$ were detected pointing to typical angucycline deoxy sugars. Three of these sugars belong to a trisaccharide $O$-glycosidically connected to $4^{\prime}-O$ of the $\beta$-D-olivose of the aglycone [1 A-H $\left(\delta_{\mathrm{H}}=5.08\right)$ to $\mathrm{C}-4^{\prime}$ $\left.\left(\delta_{\mathrm{C}}=89.3\right)\right]$. A detailed $2 \mathrm{D} \mathrm{NMR}$ analysis showed that this sugar side chain is identical with that of galtamycin B (11) and is terminated by L-aculose with its typical enone system $\left(\delta_{\mathrm{C}}=127.3,142.9,196.7\right)$. The remaining five sugars are part of a pentasaccharide $O$-glycosidically connected to $3-O$ of the aglycone $\left[1 \mathrm{D}-\mathrm{H}\left(\delta_{\mathrm{H}}=5.24\right)\right.$ to $\mathrm{C}-3$ $\left.\left(\delta_{\mathrm{C}}=82.4\right)\right]$. The position is the same as in saquayamycin A and $\mathrm{B}$. The five sugars could be confirmed by $2 \mathrm{D}$ NMR experiments $\left({ }^{1} \mathrm{H},{ }^{1} \mathrm{H}\right.$ COSY, HSQC, HMBC and $2 \mathrm{D}$ TOCSY) as three rhodinoses and two olivoses. The sequence was determined by an HMBC experiment and by ESI-MS/MS experiments of the methanol adduct 15 (Fig. 5). The HMBC experiment reveals the connection of the sugars to each other [1B-H $\left(\delta_{\mathrm{H}}=4.90\right)$ to $\mathrm{C}-4 \mathrm{~A}\left(\delta_{\mathrm{C}}=79.0\right)$; $1 \mathrm{C}-\mathrm{H}\left(\delta_{\mathrm{H}}=5.24\right)$ to $\mathrm{C}-4 \mathrm{~B}\left(\delta_{\mathrm{C}}=76.2\right) ; 1 \mathrm{E}-\mathrm{H}\left(\delta_{\mathrm{H}}=4.48\right)$ to C-4D $\left(\delta_{\mathrm{C}}=75.8\right) ; 1 \mathrm{~F}-\mathrm{H}\left(\delta_{\mathrm{H}}=4.94\right)$ to C-3E $\left(\delta_{\mathrm{C}}=80.4\right) ; 1 \mathrm{G}-$ $\mathrm{H}\left(\delta_{\mathrm{H}}=4.48\right)$ to $\mathrm{C}-4 \mathrm{~F}\left(\delta_{\mathrm{C}}=75.5\right) ; 1 \mathrm{H}-\mathrm{H}\left(\delta_{\mathrm{H}}=4.96\right)$ to $\mathrm{C}$ -

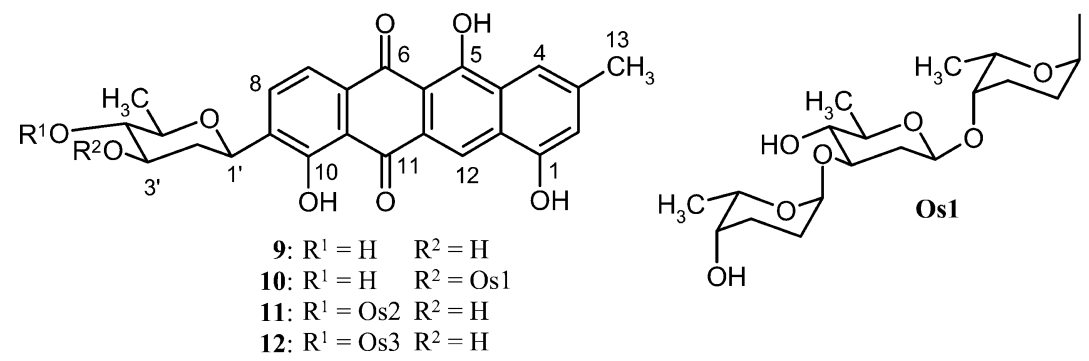
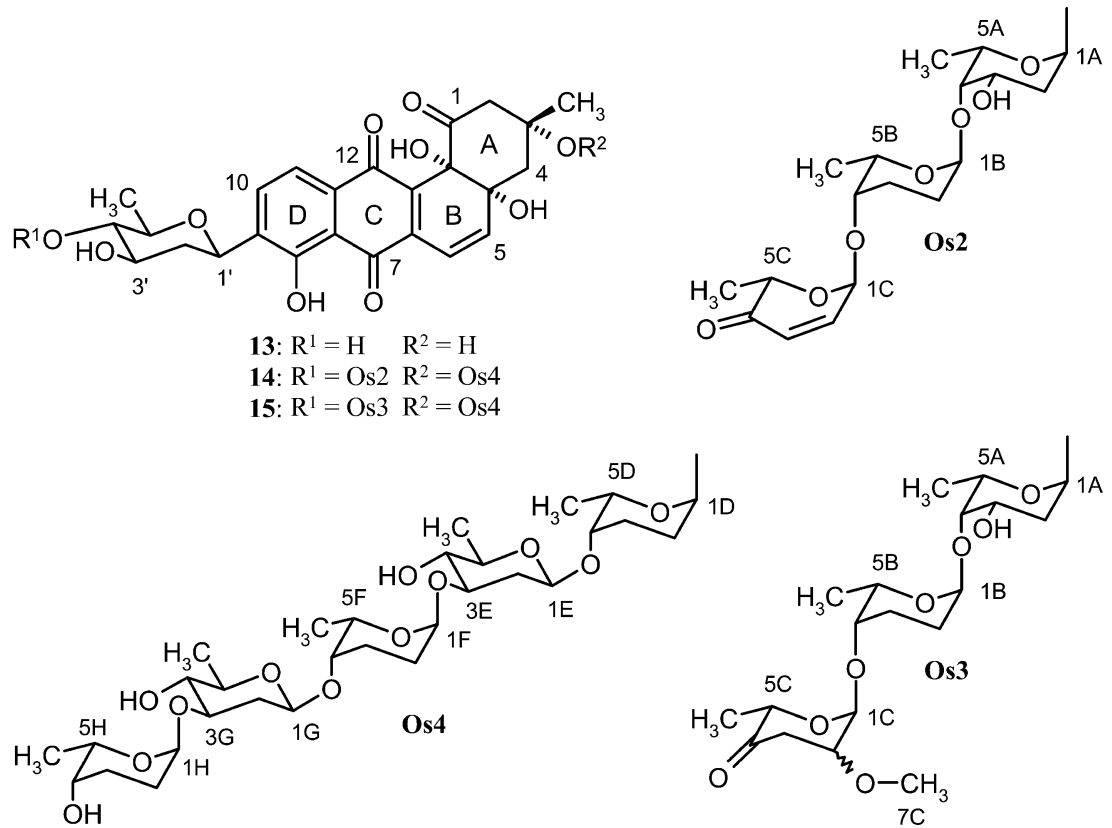

Fig. 4 Structural formulae of galtamycin B (11), saquayamycin Z (14) and related compounds. 


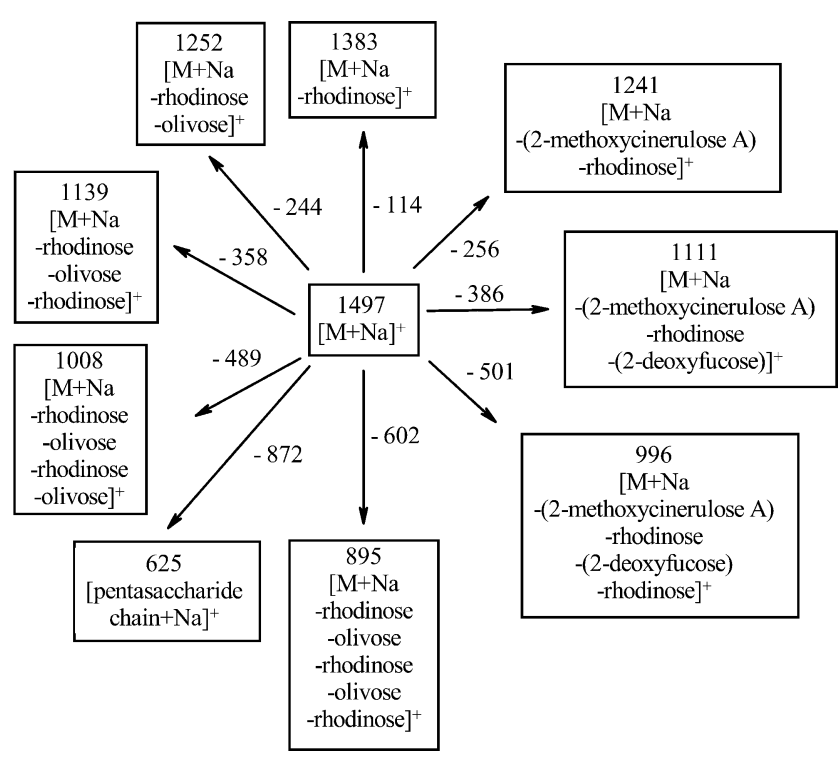

Fig. 5 Fragmentation pattern of ESI-MS/MS experiments (positive mode) of the methanol adduct $\mathbf{1 5}$.

$\left.3 \mathrm{G}\left(\delta_{\mathrm{C}}=80.7\right)\right]$. Thus saquayamycin $\mathrm{Z}(\mathbf{1 4})$ contains a $\alpha$-Lrhodinosyl- $(1 \rightarrow 3)$ - $\beta$-D-olivosyl- $(1 \rightarrow 4)$ - $\alpha$-L-rhodinosyl$(1 \rightarrow 3)$ - $\beta$-D-olivosyl-( $1 \rightarrow 4)$ - $\alpha$-L-rhodinosyl side chain with an alternating sequence rhythm. A coupled HSQC experiment proved the assumed configurations of the anomeric carbon atoms of both sugar side chains: ${ }^{1} J_{\mathrm{C}-\mathrm{H}}$ coupling constants of $156 \mathrm{~Hz}$ (C-1E and $\mathrm{C}-1 \mathrm{G})$ were typical for $\beta$-D-olivoses, $174 \mathrm{~Hz}$ (C-1A) for $\alpha$-L-2deoxyfucose, $174 \mathrm{~Hz}(\mathrm{C}-1 \mathrm{C})$ for $\alpha$-L-aculose and 166 174 $\mathrm{Hz}$ (C-1B, C-1D, C-1F and C-1G) for $\alpha$-L-rhodinoses. Both oligosaccharide side chains together led to formula 14 of saquayamycin Z (Fig. 4).

\section{Discussion}

From the cultures of Micromonospora sp. strain Tü 6368 altogether ten secondary metabolites were isolated by performing two fermentations under different conditions. The lumichromes $\mathbf{1}$ to $\mathbf{3}$ were produced without XAD supplementation, the others, belonging to angucycline/angucyclinone family $(4 \sim 7,9,11$ and 14) need this supplementation for optimum yields.

The lumichromes show a tricyclic chromophoric system similar to that of riboflavin, which carries an open chain Dribose moiety non glycosidically attached to N-10, whereas 1 -( $\alpha$-ribofuranosyl)-lumichrome (3) is the first natural product with a $\alpha$-ribofuranosyl moiety glycosidically attached to N-1.

Angucyclinones are PKS II polyketides, which can be $C$ glycosylated, e.g. by D-olivose, at position 9 of the angular core structure. The core structure itself can be varied in the late biosynthesis in different ways: (i) bishydroxylation at $\mathrm{C}-4 \mathrm{a} / \mathrm{C}-12 \mathrm{~b}$ reversing the aromaticity of ring $\mathrm{B}$ resulting in aquayamycin (13), (ii) oxidative fission of the quinone ring $\mathrm{C}$, decarboxylation and recyclisation resulting in the xanthone skeleton of retymicin (7) and (iii) rearrangement of the angular aquayamycin skeleton resulting in the fully aromatic linear tetracenequinone skeleton of galtamycinone (9) [13].

The angucyclinones and derived aglycones are glycosylated in different positions, e.g. 3'-OH, 4'-OH, 3$\mathrm{OH}$ or $12 \mathrm{~b}-\mathrm{OH}[14,15]$. Only the $4^{\prime}-\mathrm{OH}$ in the case of galtamycin B (11) and in the case of saquayamycin Z (14) both the $4^{\prime}-\mathrm{OH}$ and $3-\mathrm{OH}$ are involved. The trisaccharide of 11 and 14 is striking because of the presence of $\alpha$-L-2deoxyfucose, which is not a usual sugar constituent of the angucyclines, whereas the pentasaccharide of $\mathbf{1 4}$ in an alternating sequence rhythm contains $\beta$-D-olivose and $\alpha$-Lrhodinose, which are common sugar moieties of this group of antibiotics. Furthermore, saquayamycin $Z$ (14) is the largest angucycline so far with a molecular formula of $\mathrm{C}_{73} \mathrm{H}_{102} \mathrm{O}_{29}$ and a molecular weight of $\mathrm{M}_{\mathrm{r}}=1443$ and is assembled by the aquayamycin aglycone and eight additional deoxy sugars. Within the hitherto existing angucyclines the landomycins $\mathrm{A}$ and $\mathrm{C}$ with molecular weights of $M_{r}=1087$ and $1071[16,17]$, respectively, were the largest, each of them possesses six $O$-glycosidically bound sugar moieties.

Thus, Micromonospora sp. strain Tü 6368 seems to be an interesting candidate for studying the available glycosyl transferases in the light of their regio-, stereo- and substrate specifity. They may become valuable tools for genetically based combinatorial methods in the biosynthesis of biological active glycosides [18].

\section{Experimental}

\section{General}

NMR spectra were measured with Varian Inova-600 (600 $\mathrm{MHz}$ ), Varian Mercury-300 (300 MHz) and Varian Unity$300(300 \mathrm{MHz})$ instruments. Chemical shifts are expressed in $\delta$ values with solvents as internal standards. HRESI mass spectra were taken by Bruker Apex-Q III (7 Tesla) and DCI mass spectra by Finnigan MAT $95\left(200 \mathrm{eV}, \mathrm{NH}_{3}\right.$ as reactant gas). IR spectra of samples in pressed $\mathrm{KBr}$ discs, were recorded on a Perkin Elmer FT-IR 1600 spectrometer, the UV spectra, on a Varian Cary 3E spectrophotometer, the CD spectra, on a Jasco J 500 spectrometer and the optical rotation values, with a Perkin Elmer 343 polarimeter. TLC was carried out on silica gel $60 \mathrm{~F}_{254}$ 
plates (Merck, $0.25 \mathrm{~mm}$ ), compounds were viewed under a UV lamp at 254 and $366 \mathrm{~nm}$.

\section{1-( $\alpha$-Ribofuranosyl)-lumichrome (3)}

Yellow solid; Rf $0.22\left(\mathrm{CHCl}_{3}-\mathrm{MeOH}, 9: 1\right) ;[\alpha]_{20}^{\mathrm{D}}+319^{\circ}$ $(c=0.1, \mathrm{MeOH}) ; \mathrm{UV} \lambda_{\max }^{\mathrm{MeOH}} \mathrm{nm}(\log \varepsilon) 214$ (4.45), 254 (4.55), 340 (3.85); $\mathrm{CD} \lambda_{\max }^{\mathrm{MeOH}} \mathrm{nm}\left([\theta]^{20}\right) 259(+43864)$, 240 (-5393), $226(+7147)$; IR $v_{\max }(\mathrm{KBr}) \mathrm{cm}^{-1} 3425$, $1768,1755,1693,1682,1558,1430,1401,1355,1228$, 1129,$1039 ;{ }^{1} \mathrm{H}$ NMR $\left(300 \mathrm{MHz}, \mathrm{CD}_{3} \mathrm{OD}\right) \delta 2.54$ (s, 6H, $\left.11-\mathrm{H}_{3}, 12-\mathrm{H}_{3}\right), 3.69$ (dd, $\left.J=12.5,4.0 \mathrm{~Hz}, 1 \mathrm{H}, 5^{\prime}-\mathrm{H}_{\mathrm{A}}\right), 3.91$ (dd, $J=12.5,2.0 \mathrm{~Hz}, 1 \mathrm{H}, 5^{\prime}-\mathrm{H}_{\mathrm{B}}$ ), 4.18 (dd, $J=9.0,5.5 \mathrm{~Hz}$, $1 \mathrm{H}, 3^{\prime}-\mathrm{H}$ ), 4.22 (ddd, $\left.J=9.0,4.0,2.0 \mathrm{~Hz}, 1 \mathrm{H}, 4^{\prime}-\mathrm{H}\right), 5.13$ (t, $\left.J=5.5 \mathrm{~Hz}, 1 \mathrm{H}, 2^{\prime}-\mathrm{H}\right), 6.61\left(\mathrm{~d}, J=5.5 \mathrm{~Hz}, 1 \mathrm{H}, 1^{\prime}-\mathrm{H}\right), 7.81$ (s, 1H, 9-H), 7.93 (s, 1H, 6-H); ${ }^{13} \mathrm{C}$ NMR (75.5 MHz, $\left.\mathrm{CD}_{3} \mathrm{OD}\right)$ $\delta 20.4^{* 1}$ (C-11), 20.6*1 (C-12), 60.9 (C-5'), 71.6 (C-3'), 79.4 (C-2'), 80.9 (C-4'), 89.8 (C-1'), 128.1 (C-9), 129.2 (C-6), 139.7 (C-5a), 141.6 (C-9a), 142.7*2 (C-4a), 142.8*2 (C-10a), 143.2 (C-7), 145.1 (C-8), 157.0 (C-2), 169.2 (C$4), * 1, *^{2}$ assignments bearing the same superscript may be interchanged; ${ }^{1} \mathrm{H}$ NMR $\left(600 \mathrm{MHz}, \mathrm{DMSO}-d_{6}\right) \delta 2.48$ (s, $\left.6 \mathrm{H}, 11-\mathrm{H}_{3}, 12-\mathrm{H}_{3}\right), 3.47$ (dd, $J=12.5,4.0 \mathrm{~Hz}, 1 \mathrm{H}, 5^{\prime}-\mathrm{H}_{\mathrm{A}}$ ), $3.67\left(\mathrm{dd}, J=12.5,2.0 \mathrm{~Hz}, 1 \mathrm{H}, 5^{\prime}-\mathrm{H}_{\mathrm{B}}\right), 4.01\left(\mathrm{~m}, 2 \mathrm{H}, 3^{\prime}-\mathrm{H}\right.$, $\left.4^{\prime}-\mathrm{H}\right), 4.68$ (br s, 1H, 5'-OH), 5.04 (t, $J=5.5 \mathrm{~Hz}, 1 \mathrm{H}, 2^{\prime}-\mathrm{H}$ ), 5.54 (br s, 1H, 3'-OH), 6.41 (d, J=5.5 Hz, 1H, $\left.1^{\prime}-\mathrm{H}\right), 7.56$ (br s, 1H, 2'-OH), 7.82 (s, 1H, 9-H), 7.90 (s, 1H, 6-H), 8.09 (br s, $1 \mathrm{H}, 3-\mathrm{NH}) ;{ }^{13} \mathrm{C}$ NMR $\left(150.8 \mathrm{MHz}, \mathrm{DMSO}-d_{6}\right)$ : $\delta=19.8^{* 1}(\mathrm{C}-11), 19.9^{* 1}(\mathrm{C}-12), 59.3\left(\mathrm{C}-5^{\prime}\right), 69.6\left(\mathrm{C}-3^{\prime}\right)$, 77.5 (C-2'), $79.6\left(\mathrm{C}-4^{\prime}\right), 87.8\left(\mathrm{C}-1^{\prime}\right), 126.7$ (C-9), 127.6 (C-6), 137.6 (C-5a), 139.3 (C-9a), 141.2*2 (C-4a), 141.5*2 (C-10a), 142.7 (C-7), 143.0 (C-8), 154.5 (C-2), 166.1 (C$4),{ }^{1} * 2$ assignments bearing the same superscript may be interchanged; HRESI-MS $\mathrm{m} / \mathrm{z} 375.12972 \quad[\mathrm{M}+\mathrm{H}]^{+}$, calculated for $\mathrm{C}_{17} \mathrm{H}_{19} \mathrm{~N}_{4} \mathrm{O}_{6}$ and found.

\section{Retymicin (7)}

Yellow solid; Rf $0.54\left(\mathrm{CHCl}_{3}-\mathrm{MeOH}, 9: 1\right) ;[\alpha]_{20}^{\mathrm{D}}+54^{\circ}$ $(c=0.1, \mathrm{MeOH}) ; \mathrm{UV} \log \lambda_{\max }^{\mathrm{MeOH}} \mathrm{nm}(\log \varepsilon) 215$ (4.18), 268 (4.29), $303 \mathrm{sh}, 328 \mathrm{sh}$; CD $\lambda_{\max }^{\mathrm{MeOH}} \mathrm{nm}\left([\theta]^{20}\right) 348(+7656)$, 309 (-11146), 268 (-35325), $219(+59865)$; IR $v_{\max }$ $(\mathrm{KBr}) \mathrm{cm}^{-1} 3408,1717,1640,1616,1593,1560,1430$, 1360, 1294, 1223, 1180, 1043; ${ }^{1} \mathrm{H}$ NMR $(300 \mathrm{MHz}$, $\left.\mathrm{CD}_{3} \mathrm{OD}\right) \delta 0.97\left(\mathrm{~d}, J=6.5 \mathrm{~Hz}, 3 \mathrm{H}, 13-\mathrm{H}_{3}\right), 1.57$ (dd, $\left.J=14.0,11.5 \mathrm{~Hz}, 1 \mathrm{H}, 4-\mathrm{H}_{\mathrm{A}}\right), 1.97$ (dt, $J=14.0,3.0 \mathrm{~Hz}, 1 \mathrm{H}$, $\left.4-\mathrm{H}_{\mathrm{B}}\right), 2.20(\mathrm{~m}, 1 \mathrm{H}, 3-\mathrm{H}), 2.29(\mathrm{dd}, J=12.5,11.0 \mathrm{~Hz}, 1 \mathrm{H}$, $\left.2-\mathrm{H}_{\mathrm{A}}\right), 2.54\left(\mathrm{dt}, J=11.0,2.5 \mathrm{~Hz}, 1 \mathrm{H}, 2-\mathrm{H}_{\mathrm{B}}\right), 6.47(\mathrm{~d}, J=10.0$ $\mathrm{Hz}, 1 \mathrm{H}, 6-\mathrm{H}), 6.52$ (d, $J=10.0 \mathrm{~Hz}, 1 \mathrm{H}, 5-\mathrm{H}), 7.20$ (dd, $J=8.0,2.0 \mathrm{~Hz}, 1 \mathrm{H}, 9-\mathrm{H}), 7.24$ (t, $J=8.0 \mathrm{~Hz}, 1 \mathrm{H}, 10-\mathrm{H})$, 7.47 (dd, $J=8.0,2.0 \mathrm{~Hz}, 1 \mathrm{H}, 11-\mathrm{H}) ;{ }^{13} \mathrm{C}$ NMR $(75.5 \mathrm{MHz}$, $\left.\mathrm{CD}_{3} \mathrm{OD}\right) \delta 21.8(\mathrm{C}-13), 31.4(\mathrm{C}-3), 43.6(\mathrm{C}-4), 47.4$ (C-2), 78.4 (C-12b), 80.4 (C-4a), 116.0 (C-11), 117.8 (C-12a),
120.4 (C-6), 120.7 (C-9), 126.0 (C-11a), 126.9 (C-10), 146.3 (C-7a), 148.2 (C-8), 150.7 (C-5), 162.1 (C-6a), 176.8 (C-12), 209.3 (C-1); ${ }^{1} \mathrm{H}$ NMR (600 MHz, pyridine- $\left.d_{5}\right) \delta$ 0.95 (d, $\left.J=6.5 \mathrm{~Hz}, 3 \mathrm{H}, 13-\mathrm{H}_{3}\right), 1.77$ (dd, $J=14.0,12.0 \mathrm{~Hz}$, $\left.1 \mathrm{H}, 4-\mathrm{H}_{\mathrm{A}}\right), 2.15\left(\mathrm{dt}, J=14.0,3.0 \mathrm{~Hz}, 1 \mathrm{H}, 4-\mathrm{H}_{\mathrm{B}}\right), 2.61(\mathrm{~m}$, $1 \mathrm{H}, 3-\mathrm{H}), 2.69$ (dd, $\left.J=13.0,12.0 \mathrm{~Hz}, 1 \mathrm{H}, 2-\mathrm{H}_{\mathrm{A}}\right), 2.92$ (dt, $\left.J=12.0,3.0 \mathrm{~Hz}, 1 \mathrm{H}, 2-\mathrm{H}_{\mathrm{B}}\right), 6.29$ (d, $\left.J=10.0 \mathrm{~Hz}, 1 \mathrm{H}, 6-\mathrm{H}\right)$, 6.69 (d, $J=10.0 \mathrm{~Hz}, 1 \mathrm{H}, 5-\mathrm{H}), 7.29$ (t, $J=8.0 \mathrm{~Hz}, 1 \mathrm{H}, 10-$ H), 7.45 (dd, $J=8.0,1.5 \mathrm{~Hz}, 1 \mathrm{H}, 9-\mathrm{H}), 7.90$ (dd, $J=8.0,1.5$ $\mathrm{Hz}, 1 \mathrm{H}, 11-\mathrm{H}) ;{ }^{13} \mathrm{C}$ NMR $\left(150.8 \mathrm{MHz}\right.$, pyridine- $\left.d_{5}\right) \delta 21.5$ (C-13), 30.5 (C-3), 43.2 (C-4), 47.0 (C-2), 78.1 (C-12b), 79.6 (C-4a), 115.2 (C-11), 118.0 (C-12a), 119.3 (C-6), 120.1 (C-9), 125.8 (C-10), 125.9 (C-11a), 145.8 (C-7a), 148.4 (C-8), 150.4 (C-5), 160.2 (C-6a), 175.2 (C-12), 208.0 (C-1); HRESI-MS $m / z 329.10259[\mathrm{M}+\mathrm{H}]^{+}$, calculated for $\mathrm{C}_{18} \mathrm{H}_{17} \mathrm{O}_{6}$ and found.

\section{Galtamycin B (11)}

Red solid; Rf $0.62\left(\mathrm{CHCl}_{3}-\mathrm{MeOH}, 9: 1\right)$; UV $\lambda_{\max }^{\mathrm{MeCN}} \mathrm{nm}$ $(\log \varepsilon) 249 \mathrm{sh}, 264$ (4.57), $294 \mathrm{sh}, 485$ (4.05); IR $v_{\max }$ (KBr) 3447, 1700, 1636, 1560, 1458, 1437, 1384, 1288, 1261, 1087, 1040, $1014 \mathrm{~cm}^{-1}$; ${ }^{1} \mathrm{H}$ NMR $(600 \mathrm{MHz}$, pyridine- $\left.d_{5}\right) \delta 1.29\left(\mathrm{~d}, J=6.5 \mathrm{~Hz}, 3 \mathrm{H}, 6 \mathrm{~B}-\mathrm{H}_{3}\right), 1.42(\mathrm{~d}$, $\left.J=6.5 \mathrm{~Hz}, 3 \mathrm{H}, 6 \mathrm{~A}-\mathrm{H}_{3}\right), 1.47$ (d, $\left.J=6.5 \mathrm{~Hz}, 3 \mathrm{H}, 6 \mathrm{C}-\mathrm{H}_{3}\right)$, 1.54 (d, $\left.J=6.0 \mathrm{~Hz}, 3 \mathrm{H}, 6^{\prime}-\mathrm{H}_{3}\right), 1.76$ (br d, $J=12.5 \mathrm{~Hz}, 1 \mathrm{H}$, $\left.2 \mathrm{~B}-\mathrm{H}_{\mathrm{A}}\right), 1.85$ (q, $\left.J=12.0 \mathrm{~Hz}, 1 \mathrm{H}, 2^{\prime}-\mathrm{H}_{\mathrm{A}}\right), 2.07$ (br dd, $\left.J=13.0,3.0 \mathrm{~Hz}, 1 \mathrm{H}, 3 \mathrm{~B}-\mathrm{H}_{\mathrm{A}}\right), 2.15\left(\mathrm{~m}, 1 \mathrm{H}, 2 \mathrm{~B}-\mathrm{H}_{\mathrm{B}}\right), 2.20$ $\left(\mathrm{m}, 2 \mathrm{H}, 2 \mathrm{~A}-\mathrm{H}_{\mathrm{A}}, 3 \mathrm{~B}-\mathrm{H}_{\mathrm{B}}\right), 2.40\left(\mathrm{~s}, 3 \mathrm{H}, 13-\mathrm{H}_{3}\right), 2.54(\mathrm{dt}$, $J=14.0,3.5 \mathrm{~Hz}, 1 \mathrm{H}, 2 \mathrm{~A}-\mathrm{H}_{\mathrm{B}}$ ), 2.92 (br dd, $J=12.5,4.5 \mathrm{~Hz}$, $\left.1 \mathrm{H}, 2^{\prime}-\mathrm{H}_{\mathrm{B}}\right), 3.56\left(\mathrm{t}, J=8.5 \mathrm{~Hz}, 1 \mathrm{H}, 4^{\prime}-\mathrm{H}\right) 3.74\left(\mathrm{~m}, 2 \mathrm{H}, 5^{\prime}-\right.$ H, 4B-H), 3.87 (br dd, $J=4.0,2.0 \mathrm{~Hz}, 1 \mathrm{H}, 4 \mathrm{~A}-\mathrm{H}), 4.16$ (m, $\left.1 \mathrm{H}, 3^{\prime}-\mathrm{H}\right), 4.30$ (q, $\left.J=6.5 \mathrm{~Hz}, 1 \mathrm{H}, 5 \mathrm{~B}-\mathrm{H}\right), 4.44$ (br s, $1 \mathrm{H}$, $3 \mathrm{~A}-\mathrm{H}), 4.80^{*}(1 \mathrm{H}, 5 \mathrm{C}-\mathrm{H}), 5.06$ (br qd, $J=6.5,2.0 \mathrm{~Hz}, 1 \mathrm{H}$, 5A-H), 5.13 (br s, 1H, 1B-H), 5.16 (d, $J=11.5 \mathrm{~Hz}, 1 \mathrm{H}, 1^{\prime}-$ $\mathrm{H}), 5.42(\mathrm{~d}, J=3.5 \mathrm{~Hz}, 1 \mathrm{H}, 1 \mathrm{C}-\mathrm{H}), 5.42 *(1 \mathrm{H}, 1 \mathrm{~A}-\mathrm{H}), 6.18$ (d, $J=10.0 \mathrm{~Hz}, 1 \mathrm{H}, 3 \mathrm{C}-\mathrm{H}), 6.98(\mathrm{dd}, J=10.0,3.5 \mathrm{~Hz}, 1 \mathrm{H}$, 2C-H), 7.25 (s, 1H, 2-H), 8.03 (s, 1H, 4-H), 8.07 (d, $J=8.0$ $\mathrm{Hz}, 1 \mathrm{H}, 8-\mathrm{H}), 8.09$ (d, $J=8.0 \mathrm{~Hz}, 1 \mathrm{H}, 7-\mathrm{H}),{ }^{*}$ chemical shift assignment were made on the base of a ${ }^{1} J_{\mathrm{C}-\mathrm{H}}$ chemical shift correlation experiment; ${ }^{13} \mathrm{C}$ NMR $\left(150.8 \mathrm{MHz}\right.$, pyridine- $d_{5}$ ) see Table $1 ;{ }^{1} \mathrm{H}$ NMR $\left(600 \mathrm{MHz}, \mathrm{CDCl}_{3}\right) \delta 1.19(\mathrm{~d}, J=6.5$ $\left.\mathrm{Hz}, 3 \mathrm{H}, 6 \mathrm{~B}-\mathrm{H}_{3}\right), 1.28$ (d, $\left.J=6.5 \mathrm{~Hz}, 3 \mathrm{H}, 6 \mathrm{~A}-\mathrm{H}_{3}\right), 1.36$ (d, $\left.J=6.5 \mathrm{~Hz}, 3 \mathrm{H}, 3 \mathrm{C}-\mathrm{H}_{3}\right), 1.39$ (d, $\left.J=6.5 \mathrm{~Hz}, 3 \mathrm{H}, 6^{\prime}-\mathrm{H}_{3}\right), 1.46$ (br d, $J=12.5 \mathrm{~Hz}, 1 \mathrm{H}, 2^{\prime}-\mathrm{H}_{\mathrm{A}}$ ), 1.70 (br d, $J=13.0 \mathrm{~Hz}, 1 \mathrm{H}$, $\left.2 \mathrm{~B}-\mathrm{H}_{\mathrm{A}}\right), 1.91\left(\mathrm{~m}, 2 \mathrm{H}, 2 \mathrm{~A}-\mathrm{H}_{\mathrm{A}}, 3 \mathrm{~B}-\mathrm{H}_{\mathrm{A}}\right), 2.00$ (br dt, $J=14.0$, $4.0 \mathrm{~Hz}, 1 \mathrm{H}, 2 \mathrm{~B}-\mathrm{H}_{\mathrm{B}}$ ), 2.07 (br d, $J=12.0 \mathrm{~Hz}, 1 \mathrm{H}, 3 \mathrm{~B}-\mathrm{H}_{\mathrm{B}}$ ), 2.28 (br dt, $J=14.0,3.5 \mathrm{~Hz}, 1 \mathrm{H}, 2 \mathrm{~A}-\mathrm{H}_{\mathrm{B}}$ ), 2.45 (br s, 3H, 13$\mathrm{H}_{3}$ ), 2.60 (br d, $J=13.0 \mathrm{~Hz}, 1 \mathrm{H}, 2^{\prime}-\mathrm{H}_{\mathrm{B}}$ ), 3.09 (t, $J=8.5 \mathrm{~Hz}$, $\left.1 \mathrm{H}, 4^{\prime}-\mathrm{H}\right), 3.50$ (br s, 1H, 4A-H), 3.56 (m, 1H, $\left.5^{\prime}-\mathrm{H}\right), 3.64$ (br s, 1H, 4B-H), 3.86 (br s, 1H, 3'-H), 3.94 (br s, 1H, 3AH), 3.97 (q, $J=6.5 \mathrm{~Hz}, 1 \mathrm{H}, 5 \mathrm{~B}-\mathrm{H}), 4.50$ (br q, $J=6.5 \mathrm{~Hz}$, 
$1 \mathrm{H}, 5 \mathrm{~A}-\mathrm{H}), 4.56$ (q, $J=6.5 \mathrm{~Hz}, 1 \mathrm{H}, 5 \mathrm{C}-\mathrm{H}), 4.89$ (br d, $J=10.5 \mathrm{~Hz}, 1 \mathrm{H}, 1^{\prime}-\mathrm{H}$ ), 4.90 (br s, 1H, 1B-H), 5.09 (br t, $J=3.0 \mathrm{~Hz}, 1 \mathrm{H}, 1 \mathrm{~A}-\mathrm{H}), 5.23(\mathrm{~d}, J=3.5 \mathrm{~Hz}, 1 \mathrm{H}, 1 \mathrm{C}-\mathrm{H}), 6.09$ (d, $J=10.5 \mathrm{~Hz}, 1 \mathrm{H}, 3 \mathrm{C}-\mathrm{H}), 6.86$ (dd, $J=10.5,3.5 \mathrm{~Hz}, 1 \mathrm{H}$, 2C-H), 7.77 (br s, 1H, 2-H), 7.82 (br d, $J=8.0 \mathrm{~Hz}, 1 \mathrm{H}, 7-$ H), 7.84 (br d, $J=8.0 \mathrm{~Hz}, 1 \mathrm{H}, 8-\mathrm{H}), 8.56$ (br s, $1 \mathrm{H}, 12-\mathrm{H}$ ), $13.45 *$ (br s, $1 \mathrm{H}, 10-\mathrm{OH}$ ), 14.52* (br s, 1H, 5-OH), 4-H was not detectable, * assignment may be interchanged; ${ }^{13} \mathrm{C}$ NMR (150.8 MHz, $\mathrm{CDCl}_{3}$ ) see Table 1; HRESI-MS $\mathrm{m} / \mathrm{z}$ 803.29204 [M-H] $]^{-}$, calculated for $\mathrm{C}_{43} \mathrm{H}_{47} \mathrm{O}_{15}$ and found.

Methanol adduct 12: Red solid; $\mathrm{Rf} 0.68\left(\mathrm{CHCl}_{3}-\mathrm{MeOH}\right.$, 9:1); ${ }^{13} \mathrm{C}$ NMR $\left(150.8 \mathrm{MHz}, \mathrm{CDCl}_{3}\right)$ see Table 1; HRESIMS $m / z 835.31881[\mathrm{M}-\mathrm{H}]^{-}$, calculated for $\mathrm{C}_{44} \mathrm{H}_{51} \mathrm{O}_{16}$ and found.

\section{Saquayamycin Z (14)}

Orange solid; Rf $0.52\left(\mathrm{CHCl}_{3}-\mathrm{MeOH}, 9: 1\right) ;[\alpha]_{\mathrm{D}}^{20}-20^{\circ}$ $(c=0.05, \mathrm{AcCN}) ; \mathrm{UV} \lambda_{\max }^{\mathrm{MeCN}} \mathrm{nm}(\log \varepsilon) 217$ (4.45), 316 (3.64), 429 (3.74); IR $v_{\max }(\mathrm{KBr}) \mathrm{cm}^{-1} 3443,1700,1637$, 1564, 1441, 1375, 1079, 1013; ${ }^{1} \mathrm{H}$ NMR (600 MHz, $\mathrm{CDCl}_{3}$ ) $\delta 1.19\left(\mathrm{~d}, J=6.5 \mathrm{~Hz}, 3 \mathrm{H}, 6 \mathrm{D}-\mathrm{H}_{3}\right), 1.21(\mathrm{~d}, J=6.5 \mathrm{~Hz}, 6 \mathrm{H}$, $\left.6 \mathrm{~F}-\mathrm{H}_{3}, 6 \mathrm{H}-\mathrm{H}_{3}\right), 1.23$ (d, $\left.J=6.5 \mathrm{~Hz}, 3 \mathrm{H}, 6 \mathrm{~B}-\mathrm{H}_{3}\right), 1.27$ (d, $\left.J=6.5 \mathrm{~Hz}, 3 \mathrm{H}, 6 \mathrm{~A}-\mathrm{H}_{3}\right), 1.32 * 1$ (d, $J=6.5 \mathrm{~Hz}, 3 \mathrm{H}, 6 \mathrm{E}-\mathrm{H}_{3}$ ), $1.33^{* 1}\left(\mathrm{~d}, J=6.5 \mathrm{~Hz}, 3 \mathrm{H}, 6 \mathrm{G}-\mathrm{H}_{3}\right), 1.37$ (d, $J=6.5 \mathrm{~Hz}, 6 \mathrm{H}$, $\left.6^{\prime}-\mathrm{H}_{3}, 6 \mathrm{C}-\mathrm{H}_{3}\right), 1.38\left(\mathrm{~m}, 1 \mathrm{H}, 2^{\prime}-\mathrm{H}_{\mathrm{A}}\right), 1.40\left(\mathrm{~s}, 3 \mathrm{H}, 13-\mathrm{H}_{3}\right)$, $1.40\left(\mathrm{~m}, 1 \mathrm{H}, 2 \mathrm{D}-\mathrm{H}_{\mathrm{A}}\right), 1.54\left(\mathrm{~m}, 1 \mathrm{H}, 2 \mathrm{~F}-\mathrm{H}_{\mathrm{A}}\right) 1.57(\mathrm{~m}, 1 \mathrm{H}$, $\left.2 \mathrm{H}-\mathrm{H}_{\mathrm{A}}\right), 1.68\left(\mathrm{~m}, 2 \mathrm{H}, 2 \mathrm{E}-\mathrm{H}_{\mathrm{A}}, 2 \mathrm{G}-\mathrm{H}_{\mathrm{A}}\right), 1.70(\mathrm{~m}, 1 \mathrm{H}, 2 \mathrm{~B}-$ $\left.\mathrm{H}_{\mathrm{A}}\right), 1.76\left(\mathrm{~m}, 3 \mathrm{H}, 3 \mathrm{D}-\mathrm{H}_{\mathrm{A}}, 3 \mathrm{~F}-\mathrm{H}_{\mathrm{A}}, 3 \mathrm{H}-\mathrm{H}_{\mathrm{A}}\right), 1.83(\mathrm{~d}, J=15.0$ $\left.\mathrm{Hz}, 1 \mathrm{H}, 4-\mathrm{H}_{\mathrm{A}}\right), 1.91\left(\mathrm{~m}, 1 \mathrm{H}, 2 \mathrm{~A}-\mathrm{H}_{\mathrm{A}}\right), 1.93\left(\mathrm{~m}, 1 \mathrm{H}, 3 \mathrm{~B}-\mathrm{H}_{\mathrm{A}}\right)$, $1.97\left(\mathrm{~m}, 2 \mathrm{H}, 3 \mathrm{D}-\mathrm{H}_{\mathrm{B}}, 3 \mathrm{~F}-\mathrm{H}_{\mathrm{B}}\right), 2.02\left(\mathrm{~m}, 3 \mathrm{H}, 2 \mathrm{~B}-\mathrm{H}_{\mathrm{B}}, 2 \mathrm{H}-\mathrm{H}_{\mathrm{B}}\right.$, $\left.3 \mathrm{H}-\mathrm{H}_{\mathrm{B}}\right), 2.08\left(\mathrm{~m}, 1 \mathrm{H}, 3 \mathrm{~B}-\mathrm{H}_{\mathrm{B}}\right), 2.10\left(\mathrm{~m}, 2 \mathrm{H}, 2 \mathrm{D}-\mathrm{H}_{\mathrm{B}}, 2 \mathrm{~F}-\right.$ $\left.\mathrm{H}_{\mathrm{B}}\right), 2.25$ (br d, $\left.J=14.0 \mathrm{~Hz}, 1 \mathrm{H}, 4-\mathrm{H}_{\mathrm{B}}\right), 2.26\left(\mathrm{~m}, 2 \mathrm{H}, 2 \mathrm{E}-\mathrm{H}_{\mathrm{B}}\right.$, $\left.2 \mathrm{G}-\mathrm{H}_{\mathrm{B}}\right), 2.29\left(\mathrm{~m}, 1 \mathrm{H}, 2 \mathrm{~A}-\mathrm{H}_{\mathrm{B}}\right), 2.49(\mathrm{~d}, J=13.0 \mathrm{~Hz}, 1 \mathrm{H}, 2-$ $\left.\mathrm{H}_{\mathrm{A}}\right), 2.52\left(\mathrm{br} \mathrm{dd}, J=13.0,5.0 \mathrm{~Hz}, 1 \mathrm{H}, 2^{\prime}-\mathrm{H}_{\mathrm{B}}\right), 3.06(\mathrm{~m}, 1 \mathrm{H}$, $\left.4^{\prime}-\mathrm{H}\right), 3.08$ (m, 2H, 4E-H, 4G-H), 3.17 (d, $J=13.0 \mathrm{~Hz}, 1 \mathrm{H}$, 2- $\mathrm{H}_{\mathrm{B}}$ ), 3.24 (quint, $\left.J=6.5 \mathrm{~Hz}, 2 \mathrm{H}, 5 \mathrm{E}-\mathrm{H}, 5 \mathrm{G}-\mathrm{H}\right), 3.48$ (m, 2H, 3E-H, 3G-H), 3.50 (m, 1H, 4A-H), 3.55 (m, 1H, 5'-H), 3.56 (br s, 2H, 4D-H, 4F-H), 3.62 (br s, 1H, 4H-H), 3.65 (br s, 1H, 4B-H), 3.83 (m, 1H, 3'-H), 3.94 (br s, 1H, 3AH), 3.98 (q, $J=6.5 \mathrm{~Hz}, 1 \mathrm{H}, 5 \mathrm{~B}-\mathrm{H}), 4.08$ (q, $J=6.5 \mathrm{~Hz}, 1 \mathrm{H}$, $5 \mathrm{D}-\mathrm{H}$ ), 4.13 (q, $J=6.5 \mathrm{~Hz}, 1 \mathrm{H}, 5 \mathrm{~F}-\mathrm{H}$ ), 4.17 (q, $J=6.5 \mathrm{~Hz}$, $1 \mathrm{H}, 5 \mathrm{H}-\mathrm{H}), 4.46$ (br s, $1 \mathrm{H}, 4 \mathrm{a}-\mathrm{OH}), 4.48$ (br d, $J=10.0 \mathrm{~Hz}$, $2 \mathrm{H}, 1 \mathrm{E}-\mathrm{H}, 1 \mathrm{G}-\mathrm{H}), 4.48$ (m, 1H, 5A-H), 4.56 (q, $J=6.5 \mathrm{~Hz}$, $1 \mathrm{H}, 5 \mathrm{C}-\mathrm{H}), 4.58$ (br s, 1H, 12b-OH), 4.86 (d, $J=11.5 \mathrm{~Hz}$, 1H, 1'-H), 4.90 (br s, 1H, 1B-H), 4.94 (br s, 1H, 4F-H), 4.96 (br s, 1H, 4H-H), 5.08 (br t, $J=3.5 \mathrm{~Hz}, 1 \mathrm{H}, 1 \mathrm{~A}-\mathrm{H}$ ), $5.24(\mathrm{~d}, J=3.0 \mathrm{~Hz}, 1 \mathrm{H}, 1 \mathrm{C}-\mathrm{H}), 5.24^{2}(1 \mathrm{H}, 1 \mathrm{D}-\mathrm{H}), 6.09$ (d, $J=10.5 \mathrm{~Hz}, 1 \mathrm{H}, 3 \mathrm{C}-\mathrm{H}), 6.44$ (d, $J=9.5 \mathrm{~Hz}, 1 \mathrm{H}, 5-\mathrm{H}), 6.88$ (dd, $J=10.0,3.0 \mathrm{~Hz}, 1 \mathrm{H}, 2 \mathrm{C}-\mathrm{H}), 6.90$ (d, $J=9.5 \mathrm{~Hz}, 1 \mathrm{H}, 6-$ H), $7.59(\mathrm{~d}, J=8.0 \mathrm{~Hz}, 1 \mathrm{H}, 11-\mathrm{H}), 7.85(\mathrm{~d}, J=8.0 \mathrm{~Hz}, 1 \mathrm{H}$, 10-H), 12.28 (br s, 1H, 8-OH), *1 assignment may be interchanged, ${ }^{2}$ chemical shift assignment were made on the base of a ${ }^{1} J_{\mathrm{C}-\mathrm{H}}$ chemical shift correlation experiment; ${ }^{13} \mathrm{C}$ NMR (150.8 MHz, $\mathrm{CDCl}_{3}$ ) $\delta 15.1$ (C-6C), $16.0(\mathrm{C}-6 \mathrm{~A})$, $16.9^{* 1}(\mathrm{C}-6 \mathrm{D}), 17.0^{* 1}$ (C-6F, C-6H), $17.1^{* 1}$ (C-6B), 18.0 (C-6E, C-6G), 18.4 (C-6'), 24.0 (C-2H), 24.3*2 (C-2B), $24.4^{* 2}$ (C-3D), 24.5*2 (C-3F), 24.6*2 (C-3B, C-2D), 25.0 (C-2F), 25.3 (C-13), 25.4 (C-3H), 32.1 (C-2A), 36.9*3 (C2E), 37.0*3 (C-2G), $38.6\left(\mathrm{C}-2^{\prime}\right), 44.6$ (C-4), 50.1 (C-2), 64.5 (C-5A), 66.6 (C-3A), 67.0 (C-5B, C-4H, C-5H), $67.4^{* 4}(\mathrm{C}-5 \mathrm{D}), 67.5^{* 4}(\mathrm{C}-5 \mathrm{~F}), 70.5(\mathrm{C}-5 \mathrm{C}), 70.9\left(\mathrm{C}-1^{\prime}\right)$, 71.1 (C-3'), 71.7 (C-5E, C-5G), 74.2 (C-5'), 75.5*5 (C-4F), $75.6^{* 5}$ (C-4E, C-4G), 75.8 (C-4D), 76.2 (C-4B), 77.4 (C12b), 79.0 (C-4A), 79.9 (C-4a), 80.4 (C-3E), 80.7 (C-3G), 82.4 (C-3), 89.3 (C-4'), 92.6 (C-1D), 95.2 (C-1C), 97.1 (C1F), $97.4(\mathrm{C}-1 \mathrm{H}), 99.4$ (C-1B), 99.9 (C-1A), 101.2*6 (C1E), $101.4^{* 6}(\mathrm{C}-1 \mathrm{G}), 113.8$ (C-7a), 117.4 (C-6), 119.6 (C11), 127.3 (C-3C), 130.4 (C-11a), 133.4 (C-10), 138.1 (C9), $138.7^{* 7}$ (C-6a), $138.8^{* 7}$ (C-12a), 142.9 (C-2C), 145.5 (C-5), 157.9 (C-8), 182.1 (C-12), 188.1 (C-7), 196.7 (C4C), 204.8 (C-1), *1,*2,*3,*4,*5,*6,*7 assignments bearing the same superscript may be interchanged; HRESI-MS $\mathrm{m} / \mathrm{z}$ 1465.63952 $[\mathrm{M}+\mathrm{Na}]^{+}$, calculated for $\mathrm{C}_{73} \mathrm{H}_{102} \mathrm{O}_{29} \mathrm{Na}$ and found.

Methanol adduct 15: Orange solid; Rf $0.59\left(\mathrm{CHCl}_{3}\right.$ $\mathrm{MeOH}, 9: 1) ;{ }^{13} \mathrm{C}$ NMR $\left(150.8 \mathrm{MHz}, \mathrm{CDCl}_{3}\right) \delta 14.8(\mathrm{C}-$ 6C), 16.0 (C-6A), 16.9*1 (C-6D, C-6F), 17.1*1 (C-6H), 17.2 (C-6B), 18.0 (C-6E, C-6G), 18.4 (C-6'), 24.0 (C-2H), $24.4^{* 2}(\mathrm{C}-2 \mathrm{~B}), 24.5^{* 2}$ (C-3D, C-3F), 24.6*2 (C-3B, C-2D), 25.0 (C-2F), 25.2 (C-3H), 25.4 (C-13), 32.1 (C-2A), 36.9*3 (C-2E), 37.1*3 (C-2G), $38.6\left(\mathrm{C}-2^{\prime}\right), 39.7$ (C-3C), 44.7 (C4), $50.1(\mathrm{C}-2), 57.0(\mathrm{C}-7 \mathrm{C}), 64.5(\mathrm{C}-5 \mathrm{~A}), 66.7(\mathrm{C}-3 \mathrm{~A})$, $67.0^{* 4}(\mathrm{C}-5 \mathrm{H}), 67.1^{* 4}(\mathrm{C}-5 \mathrm{~B}, \mathrm{C}-4 \mathrm{H}), 67.4(\mathrm{C}-5 \mathrm{D}, \mathrm{C}-5 \mathrm{~F})$, 70.9 (C-1'), 71.1 (C-3'), 71.7 (C-5E, C-5G), 71.9 (C-5C), $74.2\left(\mathrm{C}-5^{\prime}\right), 75.5^{* 5}$ (C-4B, C-4F), 75.6*5 (C-4E, C-4G), 75.8 (C-4D), 77.4 (C-12b), 78.8 (C-2C), 79.0 (C-4A), 79.9 (C-4a), 80.5 (C-3E), 80.8 (C-3G), 82.3 (C-3), 89.5 (C-4'), 92.6 (C-1D), 97.2 (C-1F), 97.5 (C-1H), 99.5 (C-1B), 100.0 (C-1A), 100.5 (C-1C), 101.2*6 (C-1E), 101.4*6 (C-1G), 113.9 (C-7a), 117.4 (C-6), 119.6 (C-11), 130.4 (C-11a), 133.4 (C-10), 138.1 (C-9), 138.7*7 (C-6a), 138.8*7 (C-12a), 145.5 (C-5), 157.9 (C-8), 182.1 (C-12), 188.1 (C-7), 204.8 (C-1), 207.5 (C-4C), *1,*2,*3,*4,*5,*6,*7 assignments bearing the same superscript may be interchanged; ESI-MS $\mathrm{m} / \mathrm{z}$ $1497[\mathrm{M}+\mathrm{Na}]^{+}$.

Acknowledgement K. S. Wishes to thank the Deutsche Forschungsgemeinschaft (Graduiertenkolleg 227) and N. A. the DAAD for a doctoral scholarship. 


\section{References}

1. Antal N, Fiedler HP, Stackebrandt E, Beil W, Struöch K, Zeeck A. Retymicin, galtamycin B, saquayamycin $\mathrm{Z}$ and ribofuranosyllumichrome, novel secondary metabolites from Micromonospora sp. Tü 6368. I. Taxonomy, fermentation, isolation and biological activities. J Antibiot 58: 95-102 (2005)

2. Müller F, Dudley KH. The synthesis and borohydride reduction of some alloxazine derivatives. Helv Chim Acta 54: 1487-1497 (1971)

3. Ienaga K, Pfleiderer W. Synthese und Eigenschaften von Alloxazin-nucleosiden. Chem Ber 110: 3449-3455 (1977)

4. Imamura N, Kakinuma K, Ikekawa N, Tanaka H, Ōmura S. Biosynthesis of vineomycins $A_{1}$ and $B_{2}$. J Antibiot 35: 602-608 (1982)

5. Mal D, Roy HN. A concise total synthesis of brasiliquinones $\mathrm{B}$ and $\mathrm{C}$ and 3-deoxyrabelomycin. J Chem Soc Perkin Trans 1: 3167-3171 (1999)

6. Yamashita N, Harada T, Shin-ya K, Seto H. 6Hydroxytetrangulol, a new CPP32 protease inducer produced by Streptomyces sp. J Antibiot 51: 79-81 (1998)

7. Igarashi M, Sasao C, Yoshida A, Naganawa H, Hamada M, Takeuchi T. Ochracenomicins A, B and C, new benz $[a]$ anthraquinone antibiotics from Amicolatopsis sp. J Antibiot 48: 335-337 (1995)

8. Matsumoto T, Yamaguchi H, Suzuki K. Totalsynthesis of galtamycinone, the common aglycone of the C-glycosyl naphthacenequinone antibiotics. Synlett 1996: 433-434 (1996)

9. Murenets NV, Kudinova MK, Klyuev NA, Shashkov AS, Yartseva IV. Galtamycin structure. Antibiotiki Khimioter 33:
257-262 (1988)

10. Ohta K, Mizuta E, Okazaki H, Kishi T. The absolute configuration of P-1894B, a potent prolyl hydroxylase inhibitor. Chem. Pharm. Bull. 32: 4350-4359 (1984)

11. Henkel T, Zeeck A. Derivatives of saquayamycins A and B, regio- and diastereoselective addition of alcohols to the Laculose moiety. J Antibiot 43: 830-837 (1990)

12. Uchida $\mathrm{T}$, Imoto $\mathrm{M}$, Watanabe $\mathrm{Y}$, Miura $\mathrm{K}$, Dobashi $\mathrm{T}$, Matsuda N, Sawa T, Naganawa H, Hamada M, Takeuchi T, Umezawa H. Saquayamycins, new aquayamycin-group antibiotics. J Antibiot 38: 1171-1181 (1985)

13. Sezaki M, Kondo S, Maeda K, Umezawa H, Ohno M. The structure of aquayamycin. Tetrahedron 26: 5171-5190 (1970)

14. Rohr J, Thiericke R. Angucycline group antibiotics. Nat Prod Rep 9: 103-137 (1992)

15. Krohn K, Rohr J. Angucyclines: total syntheses, new structures and biosynthetic studies of an emerging new class of antibiotics. In Top Curr Chem Vol 188 Bioorganic chemistry. Ed. J. Rohr, pp. 127-195, Springer Verlag, Berlin, Heidelberg (1997)

16. Henkel T, Rohr J, Beale JM, Schwenen L. Landomycins, new angucyline antibiotics from Streptomyces sp. I. Structural studies on landomycins A D. J Antibiot 43: 492-503 (1990)

17. Weber S, Zolke C, Rohr J. Investigations of the biosynthesis and structural revision of landomycin A. J Org Chem 59: 4211-4214 (1994)

18. Hoffmeister D, Weber M, Dräger G, Ichinose K, Dürr C, Bechthold A. Rational saccharide extension by using the natural product glycosyltransferase LanGT4. Chem Bio Chem 5: 369-371 (2004) 